\title{
DEBATINDLAEG
}

\section{Vi er fælles om fremtidens velfærd}

\author{
Michael Ziegler \& Thomas Adelskov
}

Mange frivillige landet over gør en stor indsats i deres lokalsamfund. De er krumtappen i vores foreningsliv og er med deres indsats med til at gøre en stærk offentlig velfærd endnu stærkere. Både når de giver ældre medborgere en tur i en rickshaw, når de træner vores børn i sportsklubben, eller når borgere med psykiske lidelse agerer støtte for andre med psykiske lidelser.

Vi ser, at samarbejdet mellem kommuner og civilsamfund er i vækst, og mere end tre ud af fire kommuner er involveret i projekter eller aktiviteter med civile aktører. Bølgen af samarbejde mellem kommuner og civilsamfund er et udtryk for en stigende bevidsthed om, at der er behov for nye fællesskaber. Der er store forventninger til, at et tættere samarbejde mellem kommune og civilsamfund både kan styrke den frivillige indsats, fremme demokratiet og øge kvaliteten i en række kommunale opgaver.

I KL er vi optaget af, hvordan vi i kommunerne kan styrke samarbejdet med frivillige, og hvordan vi kan være med til at understøtte frivilligheden, fordi vi ser et stort potentiale i mere samarbejde med civilsamfundet, frivillige og den private sektor.

\section{Velfærd er noget vi skaber sammen}

Hvis vi skal opretholde, men også videreudvikle velfærden i Danmark, skal vi i kommu- nerne finde nye veje til at løse opgaverne. Her er det helt nødvendigt, at vi også drøfter, hvordan andre aktører i samfundet - i tæt samarbejde med kommunerne - kan bidrage til, at borgere kan leve et selvstændigt liv og mestre eget liv.

En af vejene er at nytænke og styrke samspillet mellem det offentlige, borgerne, lokalsamfundet og erhvervslivet. Det handler om at bringe alle parters ressourcer og unikke kompetencer i spil.

Det er forkert at sætte lighedstegn mellem velfærd og ydelser, der produceres af det offentlige. Nye løsninger og højere kvalitet opstår, når vi lader flere samarbejde. Vi skal involvere borgeren og dennes familie og netværk og skabe løsninger i samarbejde.

\section{Sammenhæengskraft og fællesskaber}

Frivilligt, socialt arbejde har mange potentialer og kan være med til at understøtte borgernes muligheder for at tage medansvar for egne og andres livsvilkår og medvirke til at udvikle robuste lokalsamfund og fællesskaber.

At være en del af et fællesskab kan give den enkelte borger et bedre og mere værdigt liv. Derfor har vi en fælles opgave i at sikre, at også de borgere, der har allermest brug for det, bliver en del af et fællesskab.

Netværk og frivillighed er tæt forbundne kar. Netværk kan for den enkelte bidrage til 
et fællesskab og en selvstændiggørelse, mens frivillighed giver mulighed for at bidrage og føle værdi. Foruden den værdi, den frivillige indsats skaber i lokalsamfundet, skaber det også værdi og styrket livskvalitet for de frivillige selv og kan modvirke isolation og ensomhed.

Frivilligt socialt arbejde giver borgerne mulighed for at tage medansvar for egne og andres livsvilkår. Civilsamfundet kan både være med til at skabe sammenhængskraft og stærkere fællesskaber samt bidrage til opgaveløsning og udvikling af de kommunale indsatser.

\section{Det handler om samspil}

Det er vigtigt at understrege, at det ikke handler om at flytte opgaver fra kommunen og over på frivillige. I stedet handler det om, at borgerne skal tage vare på hinanden $\mathrm{i}$ samspil med det offentlige. Civilsamfundet skal, hvor det er relevant, spille sammen med de offentlige serviceydelser, så den frivillige indsats og den offentlige indsats supplerer hinanden med hver deres særlige bidrag - til gavn for borgerne.

Vi ser allerede i dag, at den kommunale opgaveløsning foregår i et samspil med andre aktører, og vi skal være åbne og opsat på at bringe alle ressourcer i spil. Det skal vi gøre samtidig med, at vi fastholder en professionel kommunal opgaveløsning.

\section{Mangfoldighed og lokale forskelle}

Den frivillige verden strækker sig fra små lokale foreninger og enkeltpersoner til store landsdækkende organisationer. Og netop den frivillige verdens mangfoldighed skal respekteres, hvis den på bedste vis skal sættes i spil på tværs af sektorer. Kommunerne samarbejder både med det organiserede lo- kale foreningsliv samt borgere og frivillige, der ikke er organiseret gennem en forening.

Samarbejdet mellem de frivillige og det offentlige kan ske på mange måder. Fra det fast formaliserede samarbejde til den uformelle dialog. Der er ikke én rigtig metode til samarbejde. Det må være de lokale behov og traditioner, som definerer samarbejdet, og de vil ofte være forskellige på de forskellige velfærdsområder.

\section{Rammer og ledelse er vigtigt}

Undersøgelser viser, at både kommuner og civilsamfund i høj grad er tilfredse med samarbejdet med hinanden. Det er positivt, men det kræver et vedvarende fokus på, hvordan samarbejdet kan udvikles, og hvordan eventuelle udfordringer i samarbejdet kan imødekommes.

Frivillige kan bistå det faglige personale og bidrage til at udvikle opgaveløsningen. Men i KL har vi det klare synspunkt, at frivillige hverken kan eller skal erstatte fagligt personale i at løse kommunale kerneopgaver, hvor der kræves særlig uddannelse, viden eller erfaring. Her sætter også lovgivningen rammer for, hvad kommunerne som myndighed og driftsansvarlig skal levere.

Samspillet med frivillige skal ske på en måde, der anerkender de frivillige, og respekterer de præmisser, de er gået ind i et frivilligt arbejde på.

Det kræver en særlig ledelsesmæssig opmærksomhed på, hvordan man får en arbejdsform med et stærkere samspil med andre aktører til at fungere, når man i kommunerne samarbejder med og inddrager frivillige. God ledelse af frivillige handler om at motivere og anerkende de frivillige, skabe et godt samarbejde og tydeligt formidle rammerne for deres indsats.

Bevidsthed og kendskab samt den faglige forståelse blandt medarbejdere i kommunen 
og hos frivillige er nogle af nøgleordene for et godt samarbejde. En fortsat dialog om grænser, rammer og en god struktur er central for, at det gode samarbejde mellem kommunerne og organisationerne kan opretholdes.

\section{Klar rollefordeling, men ingen rigide regler}

Et andet nøglepunkt for det gode samarbejde er opmærksomhed på, at opgaverne er attraktive og passende for begge parter. Det kræver en grundig forventningsafstemning, hvor formål og målgruppe samt rollefordelingen for samarbejdet afklares. Det gode samarbejde omhandler altså både organisering af opgaverne, hvordan de offentlige medarbej- deres opgaver og de frivilliges roller adskiller sig fra hinanden, og hvordan der sikres en god og vedvarende kommunikation.

Til gengæld er det værste, vi kan gøre at opsætte rigide regler. For der er ikke noget mere demotiverende end at blive mødt med regler og bureaukrati, når man som frivillig ildsjæl gerne vil give en hånd. Det risikerer at true selve essensen i frivillighed, hvis vi forsøger at regelstyre området. Derfor er det vigtigt, at vi i kommunerne hele tiden er opmærksomme på ikke at bureaukratisere samspillet, men i stedet respektere de præmisser, frivillige hjælper på.

Hvis vi lykkes med det, kan vi frigøre en enorm ressource til stor gavn for kommunerne, dens beboere og for fællesskabet.

Michael Ziegler, formand for KL's Løn- og Personaleudvalg

Thomas Adelskov, formand for KL's Socialudvalg

e-mail: KANM@kl.dk 